\title{
Correspondence
}

\section{Report of the Working Group on the training implications of the move towards community orientated treatment}

\section{DeAr Sirs}

I wonder if other community orientated psychiatrists are as profoundly disappointed with this College document (Psychiatric Bulletin, November 1990, 14, 686-693) as I am. Essentially it advocates few changes and assumes that trainees can prepare for a revolution in mental health services going on around them with a few visits to "community settings" such as day centres and hostels and sticking firmly to the old curriculum of hospital rotational attachments. The training of psychiatrists has become fossilised in a hospital based model of care which was out of date 20 years ago.

This College document is still pushing the extraordinary nonsense that performing an accurate mental state examination can only be learnt in an acute ward setting and that case formulation and presentation is somehow achieved at a more sophisticated level when the patient is far removed from his normal family environment. Can mental phenomena be best assessed in 'pure form'-like analysing crystals separated out from a supersaturated solution? Of course not. The cultural and social context is vital to our understanding. Trainees must learn to do it in the real world.

There is an uncomfortable fear lurking behind this document that community psychiatry means "psychiatry for the less seriously disturbed or chronic patient", a total misconception of what social and rehabilitation psychiatry is about. It is because of the need to reorientate services to those with long term serious disorders that the College needs to rethink its training policy. The Working Group's report is totally inadequate in this respect. There is no recognition here of the need for training for working with other agencies, training for planning and management of services, training in home based and community assessments, training in working with care managers, training in legal and ethical issues of community treatment, training in how to develop and use an information system or auditing and evaluating services. When is the trainee to learn about the structure of housing provision, work creation, enhancing patients' friendships and social relationships? About working with the private and voluntary sectors? I could go on ad infinitum.
Clues as to desirable content of future training programmes were actually scattered throughout that same issue of the Bulletin; a paper on the use of acute beds, one on what community mental health workers really do, a further paper from the valuable TAPS project. The Bulletin is good at informing readers of new service developments. It is a pity that trainees cannot benefit from these new approaches in preparing for their own future role as consultants.

I hope the new College Dean will not let this report be the last word on training for community orientated psychiatry. The quickest way to create a species of dodo psychiatrists is to carry on providing trainees with more of the same as now. Eventually we will complain of course that mental health services are 'deskilled' and run by a bunch of amateurs who do not appreciate the wonderful things psychiatrists have to offer. If we want to play a part in the game we had better get out there on the field and make sure we are training psychiatrists confident that their position in the team is a valued one.

United Medical and Dental Schools

Elaine MURPhy

Guy's Hospital

London Bridge SE1 9RT

\section{DeAR SirS}

I should like to thank you for giving me the opportunity to reply to Professor Murphy's thoughtprovoking letter. I regret her disappointment with this College report.

I agree that trainees in psychiatry can learn how to perform the mental state examination as well as case formulation and presentation in community settings and such training is commended in the document. However, such opportunities are not widely available, and where they are, are not being fully utilised by educational supervisors. This may explain the phrase "most securely to master them" on page 689.

I believe Professor Murphy's arguments were addressed in the recommendations and finally, I should like to assure her that I do not intend to watch over the creation of "dodo" psychiatrists. This report is on the agenda of the next Central Approval Panel (which is responsible for approval visits) with the intention of reviewing our progress in ensuring that trainees become properly equipped to work in the psychiatric service which is now developing.

Fiona CaldicotT

Dean 